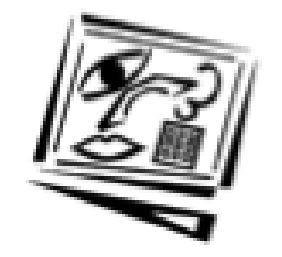

\title{
Towards research based designing for understanding fundamental concepts: The case of the web delivered generative virtual classroom for teacher education
}

\author{
Lynette Schaverien \\ University of Technology, Sydney
}

The Generative Virtual Classroom attempts sophisticated, large scale teacher education in technology and science. We show how it emerged from and contributes to a new, powerful theory of learning. Occupying an educational niche, such environments require research based design, suggesting information age responses, for diverse learning populations, to educational problems in other disciplines.

\section{Introduction}

At ASCILITE97, we described two special purpose, computer mediated learning environments for teacher education (Schaverien and Cosgrove, 1997a). Each confronted learners' recalcitrant problems in understanding seminal ideas in particular disciplines. The Generative Virtual Classroom addressed the urgent issue of encouraging Education students to develop a more sophisticated and educationally powerful understanding of learning than their typically held view that it occurs simply by being instructed. The computer mediated laboratory, Views of Electricity, helped students to deepen their understanding of the conservation principles as they apply in electric circuits, thereby putting aside their tenacious loyalty to consumption views of charge. We presented this family of learning environments as a promising attempt at negotiating the present educational crossroad, where well used educational modes of the preindustrial and industrial ages are intersecting with those being formulated for an information age (Tiffin and Rajasingham, 1995).

In 1997, the Generative Virtual Classroom existed as a fragile prototype, neither browser based nor fully integrated; and research trials of its 
effectiveness were in their early stages. Development and research were proceeding, in parallel, towards a fully integrated, browser based version. Now, such a version exists; and its development has been informed by two sustained research investigations (Allard, 1998; Sen, 1999).

ASCILITE99, with its theme of Responding to Diversity, gives us an opportunity to describe this work. We draw conclusions about the lessons learned from this case, we speculate on its impact on educational practice and we address issues of transferability to other situations.

\section{A research base for development}

The Generative Virtual Classroom emerged from a sustained research and development program investigating the early learning of technology and science. The genesis of this program lay in the early phases of the Learning in Science Project at Hamilton Teachers' College and Waikato University (1979-1984) and, in particular, that project's pioneering recognition of children's technological and scientific ingenuity (reported, for example, by Cosgrove, Osborne and Carr in 1985 and Cosgrove in 1995). Our studies, conducted some years later, revealed such ingenuity in even younger children (for example, Cosgrove and Schaverien, 1994, 1996).

Such findings demonstrated the worth of technology and science education in the early years. As well, they affirmed the effectiveness of the particular conversational researching and teaching approaches used (Cosgrove and Schaverien, 1996); and these studies themselves helped to refine these approaches. However, they also made explicit a sharp moral imperative: once the worth of technology and science learning had been affirmed and young children's enthusiasm for dealing with technological, philosophical and scientific ideas demonstrated, primary school teachers' reluctance to teach these subjects needed confronting. Small scale but sustained empirical studies revealed that, just as conversational researching and teaching approaches had succeeded in illuminating young children's ingenuity, so similar approaches could be used by a classroom based mentor to help teachers develop imaginative, rigorous and effective new teaching approaches (Schaverien and Cosgrove, 1997b).

When others were admitting almost universal failure of research based teaching innovations to penetrate classrooms (for example, White and Klapper (1994)), this mentored teacher development constituted a spectacular success. However, such one to one mentoring hardly offered a cost effective solution to the problems of barren, anachronistic technology 
and science teaching. Without a way to scale up this solution, to respond to the needs of diverse teachers in large numbers of classrooms, the moral imperative to educate teachers in supporting young children's ingenuity remained unanswered.

\section{Scaling up: Developing education students' views of learning in a generative virtual classroom}

It is in response to this precise quandary that the Generative Virtual Classroom developed. Advanced technologies for learning appeared to offer components of a possible solution. Digitised video excerpts could create, for teachers, a virtual primary school classroom with access to exemplary technology and science learning and teaching. Electronically mediated discussion could simulate a virtual tertiary classroom in which different learners could compare and contrast ideas about what they saw. A browser delivered database could store their ideas over time, for their own and others' use; and commentary, written from a particular view of learning could be provided via the web, together with related materials, for learners' provocation. It was worth investigating whether this Generative Virtual Classroom, this newly possible amalgam of computer mediated ways to learn to teach would preserve those features of face to face mentoring which appeared critical to teachers' development of sophisticated, innovative approaches. It was worth investigating whether this Generative Virtual Classroom could indeed respond to diversity.

\section{Principled design: A biological basis for generative learning}

In effect, the architecture that became the Generative Virtual Classroom constituted an acid test. What had actually been evolving over the years of this research program had been much more than simply a set of educational strategies for coping with diversity in technology and science learning and teacher education. A new biologically based theory of learning was being distilled. It first emerged from the recognition that learning is a generative act (Osborne and Wittrock, 1983; Wittrock, 1974, 1994; Minsky, 1985; Cosgrove, Osborne and Tasker, 1982). Then, it was empirically demonstrated in the philosophy, the technology and the science of learners - both young children and teachers - knowledge that had not been transmitted, but rather created anew, in the contexts in which these learners learned (Cosgrove, 1995; Cosgrove and Schaverien, 1996; Schaverien and Cosgrove, 1995). Finally, corroborated by recent advances in evolutionary epistemology (Plotkin, 1994, 1997) and neuroscience (Edelman, 1992, 1993), a biological basis for generative 
learning in technology and science could be articulated: as iterative cycles of generating and testing ideas, on their value, keeping those that survive these tests (Schaverien and Cosgrove, 1997c, Schaverien and Cosgrove, in press $a$, in press $b$ ).

\section{Design as a test of principle}

Now, the Generative Virtual Classroom appeared to offer a significant, large scale, empirical and philosophical test of this theory. Designed on the principles of this new theory of learning, this learning environment's operation, if carefully observed, had the power to evaluate the theory itself, in ways that had never before been investigated. Here, the elegant symmetry by which computer mediated learning environments respond to diversity is being made explicit: on the one hand, through their development, they have a particular view of learning, designed in, on which their response to diversity is predicated; and on the other hand, as the effectiveness of that response is being researched, they generate knowledge as to whether their underlying learning theory ought to be upheld, so influencing the form and direction of future educational provision. In any science, the learning sciences included, such theory testing is crucial to the advancement of knowledge, whether the testing upholds or refutes the theory in question.

Already, the worth of the biologically based theory of learning designed in to the Generative Virtual Classroom has been affirmed in other contexts. For Sacks (1995), it made sense of hitherto unexplained neuropsychological effects, for example, the failure of one of his patients (a man blind almost from birth) to see immediately, once his cataracts had been removed. For Thelen and others (1993), it explained the idiosyncratic nature of infants' development of psychomotor competence, in particular in their reaching for and grasping a toy. However, the idea of using computer mediated learning systems, such as the Generative Virtual Classroom, as tests of the learning theory implicit in their design, is not yet well accepted. At a recent seminar (Laurillard, 1999) in answer to this researcher's question, Laurillard (personal communication) agreed that such environments do constitute tests of the viability of learning theories. However, she admitted that her group's research had so far stopped well short of reflecting on the worth of their underlying conversational framework for learning (Laurillard, 1993): as yet, their research neither challenged it nor even exposed any of its limits. 


\section{Researching learning in the generative virtual classroom: Two tests of the worth of its underlying theory of learning}

Explicit investigation of the Generative Virtual Classroom, within the terms of the learning theory on which it was to be based, began immediately its project development team was formed. A research student (Swati) joined the team, as a participating member and as a member of the target learner population, with a view to writing a case study of the project's development (Sen, 1999). However, it soon became clear that Swati's account was beginning to centre on the sense she was making of her own learning journey as the Generative Virtual Classroom came into being. She tracked the development of her views of learning from a noticeable tentativeness (evident, to her, in her desire to align what she saw of learning with others' descriptions or categorisations of it) to an increasing ability to describe learning for herself, in her own terms, and to recognise it when it occurred. She began to make sense of the children's learning in those digitised video excerpts which would form the core of the Generative Virtual Classroom; and she drew on what she saw of the learning of other members of the project team. Interestingly, Swati notes that she was slowest to focus on and identify the characteristics of her own learning within the project team. However, when this occurred, she felt she had evolved a fully integrated and educationally powerful view of learning, one which supplied her with words to describe learning and criteria by which to recognise it. So, even before the distinctive amalgam of the Classroom came to be, Swati's autobiographical case study affirmed the effectiveness, in deepening her view of learning, of her participation in the project team. As well, the events in her account appeared to be consistent with and well explained by the particular (generative) theory of learning being designed in to this learning environment.

Of course, this student's experience of participating in the project development team, though similar in some respects to that of a learner in the fully developed environment, also differed markedly from it. Thorough going, large scale testing of this environment's capacity to respond to the diversity of learners' needs and interests, and of the consistency or otherwise of this learning system with the view of learning implicit in it, had to await development of a robust version of the Classroom, one which could be reliably delivered any time, anywhere. Unfortunately, integrating the two main components of the Classroom (its digitised video and its Filemaker Pro searchable, distributed database) in a unified, browser delivered platform posed significant technical problems. Furthermore, integrating these components without compromising the 
metaphor of the Virtual Classroom (by losing sight, on the screen, of the video which is the core of learners' work there) was even more difficult. Six months of development time was lost exploring varied options before a solution, hard coded in Cold Fusion, was suggested and pursued, resulting in the present browser based Version 3.

Meanwhile, so as not to lose even more research time, a robust enough Version 2 was subjected to a sustained research investigation. An Honours Education student (Megan) undertook an eight month case study of what happened to her views of learning as she worked in Version 2 of the Generative Virtual Classroom (Allard, 1998). This investigation was necessarily constrained: due to the afore mentioned technical difficulties, Megan did not become a part of a learning community, but worked alone in the Generative Virtual Classroom throughout her study.

In documenting the development of her thinking, Megan discerned three phases. The first phase (of just over two months' duration) was spent in detailed but comparatively superficial and tentative exploration of the video excerpts. While she made detailed journal records, Megan did not feel confident enough to enter any of her views in the community database. Nor did she feel that she could make any sense of the commentaries provided about these learning events. However, this initial phase provoked in her an urgent desire to pursue her own curiosity about learning. This she did in a second phase (of four months' duration). This second phase was marked by a period of six weeks in which she did not visit the Generative Virtual Classroom at all. Instead, Megan pursued her own ideas about learning, thinking and brain function, away from the Classroom. She noticeably gained in confidence in recording her thoughts and feelings, drawing on her everyday life experiences to test her ideas. By the end of this second phase, Megan felt drawn to return to the Generative Virtual Classroom in a final phase (of just over one month's duration). Her account of her thinking during this third phase provides evidence that she had formed a deeper, subtler appreciation of the learning events depicted in the Classroom and that she was able to articulate her thinking about them more clearly than in the intial period of her study. She appeared to be able to bring to bear her own insights (from the second phase of her study) so as to make more profound sense of the children's learning. Furthermore, choosing to analyse her own learning under the very same headings she had used to explore the children's learning in the Classroom's community database, Megan demonstrated that she recognised certain similarities between the children's and her own learning there. Summarising detailed evidence, Megan claimed the Generative Virtual Classroom had allowed her to describe learning 
accurately and boldly. Now able to move her thoughts about learning around, in words, she could identify significant changes in her knowledge state over the course of her investigation, just as Sen (1999) could. In particular, she could discern the limits of her understanding of learning. In precisely the same terms in which one of the children in the virtual classroom (Daniel) had crystallised his knowledge and his ignorance of electricity, Megan concluded,

Whilst by the end of my study I could describe and identify learning when it occurred, there were still things I wanted to know about it. Recognising that I am still unsure of what happens inside the brain when a person learns, a more critical question for me now would be, 'What is learning in itself?' (Allard, 1998, p. 109)

Megan's most enduring idea was the development of an urgent and, in some ways, even childlike fascination with the very basis of teaching: learning. Ironically, this fascination, though central to the professional practice of teaching, had not been provoked before in her four year teacher education degree.

We are now poised to undertake a full scale research investigation of the browser based version of the Classroom, with a much larger cohort of students. That investigation will explore the extent to which this learning system is successful in enhancing students' understanding of fundamental ideas about learning, in particular with respect to early technology and science learning. As well, it will shed further light on the power of the generative learning theory itself to make sense of the learning that occurs. In the meantime, however, on the basis of the two sustained, single case research studies already conducted and reported and from our knowledge of the research and development process, we can draw conclusions and speculate on the impact of this work on educational practice and on issues of transferability.

\section{An educational niche: Research based designing for understanding fundamental concepts}

We already know that, in at least two cases, this computer mediated learning system has enabled students, through their own efforts, to develop sophisticated ideas about learning. To this extent, then, the diverse needs of individuals from different cultural backgrounds, with different life experiences and world views have been met. We have already advanced the following set of features (Schaverien and Cosgrove, 1997a) which might explain such effectiveness: 


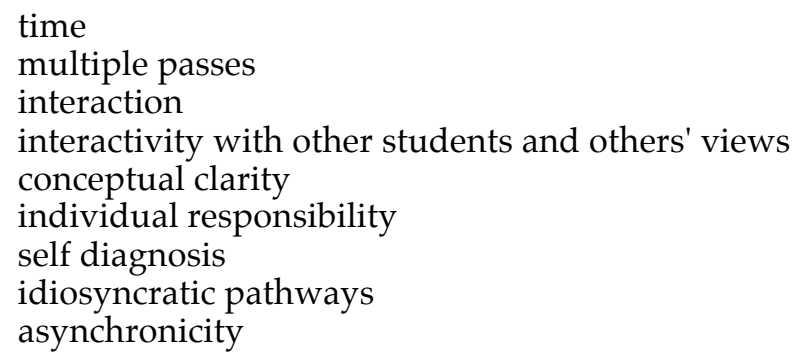

Two years on, we know a little more about the dynamics of this success, dynamics which can be understood in terms of these environments' underlying learning theory. For Laurillard (1993), learning is a teacher led, Socratic conversation between teacher and student; hence, in computer mediated environments, successful learning hinges on a student's appropriation of, or at the very least, engagement with the teacher's narrative line. In the Generative Virtual Classroom, however, learning is conceived as generative and iterative, a natural, active, idiosyncratic behaviour of students. So, there can be no pre-set narrative line to follow. Rather, a rich and complex learning environment is set up, subtly if deliberately, so as to provoke sense making by learners. For example, the community database, in which learners are encouraged to record their ideas, has cells labelled so as to focus learners' attention on salient features of learning behaviour (such as generating key ideas, testing those ideas and progression of ideas). Narrative commentaries delve deeply into aspects of the children's learning depicted in the digitised video excerpts, often comparatively insignificant aspects which learners might otherwise have missed, provoking their thinking about whether such interpretation is justified or useful and why or why not. Such environments appear to lead inexorably to learners' evolving, for themselves, their own narrative or, more particularly, interrogative line (or lines); and, if given unhurried opportunities to do so, they appear to pursue these inquiries relentlessly over days, weeks or even months. In the Generative Virtual Classroom, so far, the most common, urgent, student driven inquiries appear to centre on what learning is. It seems as if this computer mediated learning environment constitutes a dynamic system, self organising around this kind of question, much as if it were an attractor well. 
That this happens is no surprise to us as developers of these environments, although it is gratifying that we have been able to engineer, remotely, similar engagement to that which we know to happen face to face. After all, as is clear from the long lead up description in this paper, these environments are based soundly on prior research. A learner population's difficulty with seminal ideas in a discipline is first carefully identified. Then, well established ways of dealing with such difficulties, often in individual cases and without computer mediated intervention, are scrutinised. The art and the science lie in setting up an environment in which students cannot help but formulate and pursue a question or a cluster of questions which will lead to a deepening conceptual grip of their discipline.

\section{Reverse engineering learning: An educational design task}

Crystallised in this form, the task for educational designers is an altogether different and much more subtle one than has been imagined before. Rather than spelling out an explicit sequence of questions or activities to be slavishly tracked or imitated by learners, the design task is much more like that of a forensic detective, reverse engineering a crime. In developing the Generative Virtual Classroom, we asked ourselves such questions as: What might make a student hold a particular view of learning? What might coax learners to discard their prior views of learning? In what circumstances might a generative view prove especially valuable? And we answered them from our previous research where we could. This led us to the design of various components of the Generative Virtual Classroom, to the choice of particular video excerpts and to the form and content of the narrative commentaries. Doubtless, as we continue to research this learning system with a larger population of learners, individual failures and successes, as students hold on to prior views or relinquish them in favour of new ones, will provoke us to adapt existing features of the Classroom and add new ones. Our studies of learning are unravelling the values which keep learners' existing beliefs in place or lead to their subsumption or replacement by other ideas. In this, our analysis resembles Thagard's (1992) mapping of those ground breaking conceptual revolutions which have marked the progress of many different sciences.

It will now be clear that these learning environments occupy a very special educational niche in an information age characterised by its richness and diversity. They are not designed to be wells of information, nor to provide a complete curriculum in a discipline, nor simply as a question guided tutoring system. Rather, they press advanced technologies for learning 
into service as a part of the long line of attempts to assist learners with key concepts which are notoriously difficult to learn and which are known to impede future progress. As such, they respond to Papert's (1980) challenge to "think in a fundamental way about science in relation to the way people think and learn it" (p. 188). To this extent, these learning environments might well offer useful, if early, models for thinking about learning in other domains in which such key and challenging concepts exist, where research has exposed their difficulty for learners and where potentially effective ways forward have been identified. In return, these learning environments will continue to play a prominent part, in their own right, in generating educational knowledge and advancing our theorising of learning.

\section{Acknowledgments}

I acknowledge with gratitude the development work of Richard Trowsdale, the multimedia designer whose commitment to the Generative Virtual Classroom resulted in the current version. I am also grateful to Justin McLean who solved the particular technical problem which had obstructed progress towards a browser based platform and James Sawers who, having worked on the prototype version, has continued to contribute to its subsequent development. It was Mark Cosgrove who seeded the idea which inspired this project, Shirley Alexander whose Institute for Interactive Multimedia significantly assisted its development and the CUTSD Committee whose financial support and trust in our proof of concept ensured that it actually came to be. I thank Megan Allard and Swati Sen for their enthusiastic, pioneering research in the Generative Virtual Classroom and for their permission to report their findings here.

\section{References}

Allard, M. (1998). What is learning in itself? One teacher education student's autobiographical account of her developing views of learning in the Generative Virtual Classroom. Unpublished Bachelor of Education (Honours) thesis, University of Technology, Sydney, Sydney.

Cosgrove, M. (1995). A study of science-in-the-making as students generate an analogy for electricity. International Journal of Science Education, 17(3), 295-310.

Cosgrove, M., Osborne, R. and Carr, M. (1985). Using practical and technological problems to promote conceptual change. In R. Duit, W. Jung and C. Rhoneck (Eds.), Aspects of understanding electricity: Proceedings of an international workshop. Kiel: Institut fur die Pedagogik der Naturwissenschaften. 
Cosgrove, M., Osborne, R. and Tasker, R. (1982). Toward generative learning. (Working paper No. 205). Science Education Research Unit, University of Waikato - Hamilton Teachers' College, Hamilton, New Zealand.

Cosgrove, M. and Schaverien, L. (1996). Children's conversations and learning science and technology. International Journal of Science Education, 18(1): 105-116.

Cosgrove, M. and Schaverien, L. (1994). Technology learning 1: Towards a curriculum for children who are technologists. International Journal of Technology and Design Education, 4, 227-240.

Edelman, G. (1992). Bright Air, Brilliant Fire: On the matter of the mind. London: Basic Books.

Edelman, G. (1993). Neural Darwinism: Selection and reentrant signaling in higher brain function. Neuron, 10, 115-125.

Laurillard, D. (1999, August). The role of the new media in changing students' engagement with knowledge. Paper presented at a Committee for University Teaching and Staff Development seminar, Macquarie University, Sydney.

Laurillard, D. (1999). Personal communication (26 August).

Laurillard, D. (1993). Re-thinking University Teaching. Milton Keynes; Open University Press.

Minsky, M. (1985). The Society of Mind. New York: Touchstone.

Osborne, R. and Wittrock, M. (1983). Learning science: A generative process. Science Education, 67(4): 489-508.

Papert, S. (1980). Mindstorms: Children, computers and powerful ideas. New York: Basic Books.

Plotkin, H. (1997). Evolution in Mind: An introduction to evolutionary psychology. London: Penguin Books.

Plotkin, H. (1994). The Nature of Knowledge. London; Allan Lane, the Penguin Press.

Sacks, O. (1995). To see and not see. In O. Sacks, An Anthropologist on Mars (pp. 108152). New York: Alfred A. Knopf.

Schaverien, L. and Cosgrove, M. (in press a). A biological basis for generative learning in technology-and-science: Part I - A theory of learning. International Journal of Science Education.

Schaverien, L. and Cosgrove, M. (in press b). A biological basis for generative learning in technology-and-science: Part II - Implications for technology-andscience education. International Journal of Science Education.

Schaverien, L. and Cosgrove, M. (1997a). Computer based learning environments in teacher education: Helping students to think accurately, boldly and critically. In R. Kevill, R. Oliver and R. Phillips (Eds). ASCILITE97: What Works and Why? 
Conference Proceedings: 14th Annual Conference of the Australian Society for Computers in Learning in Tertiary Education (pp. 544-550). Perth, WA: Curtin University of Technology Press.

Schaverien, L. and Cosgrove, M. (1997b). Learning to teach generatively. Journal of the Learning Sciences, 6(3), 317-346.

Schaverien, L. and Cosgrove, M. (1997c). A biological basis for generative learning in science. In C.E. Oxnard and L. Freedman (Eds.) Perspectives in Human Biology: Human Trends and Lessons from the Past (pp. 41-56). Perth: Centre for Human Biology and Singapore: World Scientific Publishing.

Schaverien, L. and Cosgrove, M. (1995). Technology learning 2: Towards reawakening the technologists within primary teachers. International Journal of Technology and Design Education, 5, 51-58.

Sen, S. (1999). Towards new technologies for advanced teacher education: An autobiographical study. Unpublished Master of Education (Honours) thesis, University of Technology, Sydney, Sydney.

Thagard, P. (1992). Conceptual Revolutions. Princeton, New Jersey: Princeton University Press.

Thelen, E., Corbetta, D., Kamm, K., Spencer, J., Schneider, K. and Zernicke, R. (1993). The transition to reaching: Mapping intention and intrinsic dynamics. Child Development, 64, 1058-1098.

Tiffin, J. and Rajasingham, L. (1995). In Search of the Virtual Class. Wellington: Routledge.

White, A. and Klapper, M. (1994). An agenda for science education research. Cognosos, 3(3), 1-10.

Wittrock, M. (1994). Generative science teaching. In P. Fensham, R. Gunstone and R. White (Eds.), The Content of Science: A constructivist approach to its teaching and learning (pp. 29-38). London: The Falmer Press.

Wittrock, M. (1974). Learning as a generative process. Educational Psychologist, 11(2), 87-95.

Lynette Schaverien

Learning Systems Research and Development Group

Faculty of Education

University of Technology, Sydney

Email: L.Schaverien@uts.edu.au

http:/ / www.education.uts.edu.au/lsrdg/ 